\title{
Rapid Ecological Assessment of benthic indicators of water quality: a successful capacity-building experience for Brazilian postgraduate students in ecology
}

\author{
Callisto, M. ${ }^{a *}$, Ribeiro, AS. ${ }^{b}$, Santana, VB. ${ }^{c}$, França, JS. ${ }^{a}$, Ligeiro, R $^{a}$, Ferreira, WR.$^{a}$, \\ Silva, D. ${ }^{a}$, Castro, D. ${ }^{a}$, Tupinambás, TH. ${ }^{a}$, Santana, D. ${ }^{b}$, Souza, B. ${ }^{b}$, Gonçalves, F. ${ }^{b}$, \\ Rodrigues, L. ${ }^{b}$, Andrade, CB. ${ }^{c}$, Sales, SCM. ${ }^{a}$, Souza, R. ${ }^{c}$

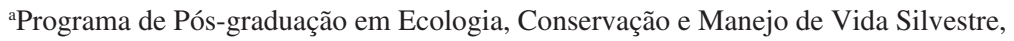 \\ Universidade Federal de Minas Gerais - UFMG, Av. Antônio Carlos, 6627, Pampulha, \\ CEP 31270-901, Belo Horizonte, MG, Brazil \\ bNúcleo de Pós-graduação em Ecologia e Conservação, Universidade Federal de Sergipe - UFS, \\ São Cristóvão, SE, Brazil \\ ${ }^{\mathrm{c}}$ Superintendência de Biodiversidade, Áreas Protegidas e Florestas, Secretaria de Meio Ambiente e Recursos Hídricos, \\ Aracaju, SE, Brazil \\ *e-mail: callistom@ufmg.br
}

Received August 17, 2010 - Accepted November 8, 2010 - Distributed 30 November, 2011

(With 4 figures)

\begin{abstract}
Rapid Ecological Assessment protocols are important tools for the training of postgraduate students, as well as the collection of data on poorly-known and protected areas with the potential for the preservation of water supplies for urban areas. The objective of this study was to perform a survey of water quality and diversity of benthic macroinvertebrates in two sub-basins at the Mata do Junco Wildlife Refuge in the Brazilian state of Sergipe. The collection of data in the field, laboratory processing, and the interpretation and discussion of data were conducted in groups by students from two postgraduate programmes in Ecology and Conservation (UFMG and UFS), personnel of the state environment agency (SEMARH), school teachers from the local town of Capela, and members of the reserve's voluntary fire brigade. The results of the assessment were organised, analysed, and presented at the reserve headquarters in the form of posters, for the development of environmental education activities with pupils from local schools, as well as contributing to a SEMARH seminar. Samples were characterised by distinct taxonomic compositions and diversity, as confirmed by MDS and additive partitioning of diversity analyses. The gravel substrate presented the lower mean taxonomic richness in each sampling unit $\left(\alpha_{1}=28 \%\right)$, while the average difference among samples ( $\beta_{1}$ diversity) was elevated for both substrates (39\% for leaf litter, $41 \%$ for gravel), reflecting the pronounced variation among samples, even adjacent ones within the same stream. Diversity between streams was lower in the case of leaf litter in comparison with gravel $\left(\beta_{2}=21\right.$ and $31 \%$, respectively). A total of 57 fish specimens were collected with a predominance of individuals of the orders Characiformes (62\%) and Perciformes (21\%). This rapid ecological assessment confirmed the importance of the conservation unit and emphasised the need for its continuation, given its importance for the maintenance of water quality and its other ecological services, such as the conservation of the region's aquatic biodiversity and providing the local town of Capela (circa 20,000 inhabitants) with its water supply, the Mata do Junco being its only source.
\end{abstract}

Keywords: in situ training, postgraduate programme, biodiversity conservation, protected areas.

\section{Avaliação ecológica rápida de indicadores bentônicos de qualidade de água: uma experiência de sucesso na formação de pós-graduandos em ecologia no Brasil}

\begin{abstract}
Resumo
Protocolos de avaliação ecológica rápida são ferramentas importantes para treinamento de pós-graduandos e levantamento de informações em áreas pouco conhecidas. O objetivo deste estudo foi realizar um levantamento de qualidade de água e diversidade de macroinvertebrados bentônicos em duas sub-bacias em uma área protegida. Atividades de campo, processamento em laboratório, interpretação e discussão de dados foram realizados em grupos com a participação de representantes dos Programas de Pós-graduação em Ecologia da UFMG e da UFS, SEMARH, professores do município de Capela e "brigada voluntária de incêndio" do Refúgio de Vida Silvestre (RVS) Mata do Junco em Sergipe. Os resultados foram sintetizados, analisados e disponibilizados na Unidade de Conservação (UC) RVS Mata do Junco na forma de banners de divulgação, atividades de educação ambiental com alunos de escolas locais e em um seminário
\end{abstract}


de recursos hídricos no estado de Sergipe. As amostras de fundo apresentaram composições taxonômicas e diversidade diferentes, como mostraram as análises de ordenação MDS e de partição aditiva da diversidade. O substrato cascalho apresentou menor riqueza taxonômica média em cada unidade amostral $\left(\alpha_{1}=28 \%\right)$ e a diferença média entre amostragens (diversidade $\beta_{1}$ ) foi elevada nos dois casos (39\% em folhiço, $41 \%$ em cascalho), indicando a alta variação que há entre amostras espacialmente próximas em um mesmo riacho. A diversidade entre riachos foi menor em folhiço do que em cascalho ( $\beta_{2}=21$ e $31 \%$, respectivamente). Foram capturados 57 peixes, com predomínio de Characiformes (62\%) e Perciformes $(21 \%)$. Esta avaliação ecológica rápida corrobora a importância da criação e manutenção desta unidade de conservação, a fim de manter a boa qualidade de suas águas e serviços ecológicos, destacando-se a conservação da biodiversidade aquática e o abastecimento do município de Capela, com cerca de 20 mil habitantes que têm no RVS Mata do Junco seu único manancial de abastecimento de água.

Palavras-chave: treinamento "in situ”, pós-graduação, conservação biodiversidade, áreas protegidas.

\section{Introduction}

Protected areas are effective at safeguarding forest cover, when the principal objective is to conserve habitats and diversity, and avoid deforestation. However, reserves are not necessarily effective against hunting pressure, and are often too small to sustain viable populations of many species (Adeney et al., 2009). In Brazil, in addition, there is a scarcity of trained personnel, and most conservation units are under-staffed (Brooks et al., 2006; Mittermeir et al., 2005), especially considering the need for data on species distributions and vulnerability, and the extinction risk of a representative subset of species (Hanson et al., 2009). There is a clear need for the provision of funding for specific training programmes at local universities (Scarano, 2007), as well as the development of management protocols for the orientation of local political leaderships.

The decision of the United Nations to promote 2010 as the International Year of Biodiversity highlights the shortcomings between the urgency of the measures required and the current levels of commitment (Stuart et al., 2010). Young conservationists face an immensurable biodiversity crisis, with current species extinction rates as much as one thousand times higher than background rates. Urgent investment in capacity-building is obviously needed, and this has been a priority in Brazil in recent years, where it has involved federal, state and local agencies and institutions, as well as NGOs, field technicians and managers of protected areas interested in conservation biology. The development of local leaderships and capacity-building initiatives has the potential to guarantee the success of conservation initiatives in terms of the area protected, reduction in deforestation rates and population decline, as well as influencing policy-making and legislation at local, regional, and national levels.

Little is known of the diversity of tropical "hotspots" (Myers et al., 2000) in comparison with their temperate counterparts (Boyero, 2000; Yule et al., 2010), especially when it comes to their aquatic systems. Tropical forests contain the majority of terrestrial species diversity, and the Brazilian Atlantic Forest biome is a prominent hotspot, especially given that less than $3 \%$ of its original forest cover remains (Fonseca et al., 2007). Between one and two million square kilometres are deforested per decade worldwide, resulting in the release of considerable quantities of carbon into the atmosphere (Joppa et al., 2008). Despite its importance, the related loss of the water quality of aquatic systems is still relatively poorly understood (Brooks et al., 2006). Fortunately, there is a growing assumption that Brazilian aquatic ecosystems are increasingly threatened by anthropogenic impacts (Pompeu et al., 2005; Moreno and Callisto, 2006; Moulton and Wantzen, 2006 and references therein).

Rapid bioassessment protocols are used to assess the biological quality of the water and the ecological integrity of aquatic ecosystems (Barbosa and Callisto, 2000). While these procedures offer the advantages of low cost and reduced time in the field and laboratory, they must be evaluated carefully in order to guarantee the quality of the data collected (Maltichik and Callisto, 2004). The taxonomic resolution of this type of analysis varies from genus to order. A higher resolution tends to be used in most studies, given its more favourable cost-benefit ratio in comparison with the identification of species (Buss and Vitorino, 2010).

In this context, an important recent initiative of the Brazilian Higher Education Authority (CAPES) has been the installation of a postgraduate exchange programme, which permits systematic interchange between postgraduate courses in different regions of the country. A programme was established between the postgraduate programmes in Ecology at the federal universities of Minas Gerais (UFMG), in southeastern Brazil, and Sergipe (UFS), in the northeast of the country. As part of the exchange, a short-term field course was conducted in March, 2010, at the Mata do Junco Wildlife Refuge in Sergipe, which protects an important area of Atlantic Forest, and in particular, the local population of the endangered endemic monkey, Callicebus coimbrai Kobayashi \& Langguth, 1999. This course promoted collaboration between academic researchers, state and federal environment technicians, and postgraduate students. Assessment of aquatic ecosystems was based on the AquaRap approach (Mittermeier and Forsyth, 1992; Chernoff et al., 1996), which permits the reliable evaluation of a large number of sites during a short period of time (Barbosa and Callisto, 2000). The objective 
of this study was to perform a survey of water quality and diversity of benthic macroinvertebrates in two sub-basins, based on physical and chemical characteristics, diversity of macroinvertebrates and environmental education practices. It is hoped that these same areas will be included in long-term ecological monitoring programs, based on the collection of more detailed data, including more ample inventories and surveys, and biomonitoring procedures.

\section{Material and Methods}

\subsection{Study area}

The Mata do Junco State Wildlife Refuge was created in 2007 with the primary objective of protecting the endangered primate $C$. coimbrai. The reserve is located in the $197.7 \mathrm{~km}^{2}$ basin of the Japaratuba river ( $10^{\circ} 14^{\prime} 00^{\prime \prime}$ and $10^{\circ} 48^{\prime} 00^{\prime \prime} \mathrm{S} ; 37^{\circ} 18^{\prime} 00^{\prime \prime}$ and $36^{\circ} 48^{\prime} 00^{\prime \prime} \mathrm{W}$ ), which is within planning unit 204, in the municipality of Capela, in the Brazilian state of Sergipe (Cunha, 2001). The Mata do Junco sub-basin is formed by 14 springs, only three of which are preserved. Six others have been altered, while the remaining five have been degraded, based on an analysis of the vegetation surrounding the spring, and the type of land use of the adjacent area (Ferreira et al., 2007).

The two sub-basins - Lagartixo and Bica do Estreiro that originate within the conservation unit were evaluated in the present study. Five points were sampled in the Lagartixo sub-basin: P01 - spring in a semi-lentic reach with abundant deposits of leaf detritus; P02 - downstream from this spring, with extensive gallery forest; $\mathrm{P} 03$ - spring located in an area with limited anthropogenic impact; P04 - stream with dark-colored water, deposits of clay, downstream from P03; P05 - reach downstream from the catchment station of the Autonomous Water and Sewage Service (SAAE) of the municipality of Capela, formed by the confluence of the two springs. The other four points were located in the Bica do Estreito sub-basin: P06 - darkwater stream adjacent to a bamboo stand; P07 - stream located downstream from the Bica do Estreito spring; P08 - stream within a bamboo stand, downstream of the confluence of points P06 and P07; P09 - narrow stream, after a dam, flows into the main stream at P08.

\subsection{Methods}

\subsubsection{Physical and chemical characteristics}

A rapid assessment protocol for the evaluation of ecological conditions and habitat diversity in hydrographic basins, as proposed by Callisto et al. (2002a), was adopted for the present study. In addition, a qualitative survey of the vegetation in the surrounding area was conducted using a procedure adapted from Chagas (2009).

At the nine in situ sample points (P01-09), data on the $\mathrm{pH}$, electrical conductivity, resistivity, temperature, and total dissolved solids in the water were collected using a multiparameter Yellow Springs apparatus. The air temperature, and the depth, width, and flow velocity of the stream reaches were also measured. In the laboratory, turbidity was analysed using a desktop turbidity-meter, total alkalinity was determined by the Gran method (Carmouze, 1994), while dissolved oxygen concentrations were measured by the Winkler method. Water samples were collected for laboratory analysis in order to determine total-P and total-N concentrations, following Golterman et al. (1978) and Mackereth et al. (1978), respectively.

Diversity of freshwater bioindicators

Samples of the organic (leaf litter deposits) and inorganic (gravel) substrates were collected from each stream. Both types of material are common in the two sub-basins. Five replicates of each substrate were randomly collected from each system (50 meters reach), using a Surber-type sampler with an area of $0.09 \mathrm{~m}^{2}$ and a $250 \mu \mathrm{m}$ mesh. In the laboratory, the samples were washed in $250 \mu \mathrm{m}$-mesh sieves and all organisms were separated and identified to the family level.

A Non-Metric Multidimensional Scaling (NMS) analysis based on Bray-Curtis distances was used to determine whether the samples from the two types of substrate had distinct taxonomic composition. The difference between the richness and density of invertebrates associated with the leaf banks of the stream bottoms was evaluated statistically using a $t$-test. An additive partitioning analysis of diversity (as proposed by Veech et al., 2002) was applied separately to the data from each substrate with the objective of identifying the spatial scales that contribute most, proportionately, to total richness. The mean richness observed in the Surber samples was defined as the diversity on the lowest scale analysed $\left(\alpha_{1}\right)$. The difference among samples was defined as $\beta_{1}$ diversity, while the difference between streams was denominated $\beta_{2}$ diversity.

The multimetric benthic index developed by Ferreira et al. (2011) was used for the evaluation of water quality. This index evaluates a set of benthic parameters (Richness, \% Oligochaeta, \% CHOL - Chironomidade + Oligochaeta, $\%$ EPT - Ephemeroptera, Plecoptera and Trichoptera, $\%$ collector-gatherers and BMWP-CETEC - Biological Monitoring Working Party). Each parameter is attributed a score (1,3, or 5) according to the response of the organism to impact (Table 1). The index is the sum of these scores, which has a maximum possible value of 30 . Scores are allocated to four categories of water quality: bad (6-12),

Table 1. Metrics used in benthic biotic index calculation (Taxonomic richness, \% Oligochaeta, \% CHOL Chironomidae + Oligochaeta, \% EPT - Ephemeroptera, Plecoptera, Trichoptera, \% Collector-gatherers and BMWP - CETEC - Biological Monitoring Working Party).

\begin{tabular}{lccc}
\hline \multirow{2}{*}{\multicolumn{1}{c}{ Metrics }} & \multicolumn{3}{c}{ Scores } \\
\cline { 2 - 4 } & $\mathbf{5}$ & $\mathbf{3}$ & $\mathbf{1}$ \\
\hline Richness & $\geq 9$ & $8-6$ & $5 \leq$ \\
$\%$ Oligochaeta & $\leq 5$ & $6-46$ & $\geq 47 \leq 97$ \\
$\%$ CHOL & $\leq 73$ & $74-86$ & $\geq 87 \leq 100$ \\
$\%$ EPT & $\geq 6$ & $5-3$ & $\leq 2$ \\
$\%$ Collector-gatherers & $\leq 64$ & $65-83$ & $\geq 84 \leq 99$ \\
BMWP-CETEC & $\geq 36$ & $35-18$ & $\leq 17$ \\
\hline
\end{tabular}


average (13-18), good (19-24), and very good (25-30). The benthic macroinvertebrate communities were classified in functional feeding groups according to the feeding strategies of these organisms in the ecosystems under analysis.

Samples of the benthic macroinvertebrates floating in the streams were collected using drift nets $\left(2500 \mathrm{~cm}^{2}\right.$ in area, with a $250 \mu \mathrm{m}$ mesh), which were set for a period of 24 hours. Three drift nets were set in each stream, and differences between streams were evaluated through estimates of taxonomic richness, equitability (Pielou), diversity (Shannon-Wiener) and density (individuals per $\mathrm{m}^{3}$ ). The material collected in the nets was removed, washed in a sieve, processed, and identified in the laboratory. The width $(\mathrm{m})$, depth $(\mathrm{m})$, flow velocity $(\mathrm{m} / \mathrm{s})$, and discharge $\left(\mathrm{m}^{3} / \mathrm{s}\right)$ of the stream at each were measured. Differences between streams in the composition and diversity of the macroinvertebrate fauna were tested using Student's $t$-test.

Qualitative samples of the local icthyofauna were collected at two points in each stream, P01 and P05 in the Lagartixo, and P06 and P08 in the Bica do Estreito. The fish were captured in D-shaped hand-nets (1 mm mesh) and $3 \mathrm{~m}$-long trawls (1 $\mathrm{m}$ high, $1 \mathrm{~mm}$ mesh). The specimens collected were fixed in $10 \%$ formalin, weighed on a 0.01 -g precision scale, measured, and identified. The analysis of the stomach contents of a sample of 39 fish was used as a complementary approach to the inventory of the local benthic macroinvertebrates. The stomachs were retrieved via ventral incision, and their contents were investigated under a magnifying glass. The benthic macroinvertebrates were separated and identified to the lowest taxonomic level (family).

\subsubsection{Environmental education}

A number of environmental education activities were conducted during the study period, involving pupils from four local schools (three municipal and one state-run). The pupils included children, adolescents, and adults with special needs. The activities were: a) presentation of a documentary on the Mata do Junco Wildlife Refuge; b) interactive exhibition using four different strategies: i) free drawing for the assessment of existing knowledge; ii) presentation of posters providing information on the principal bioindicator organisms and their habitat; iii) mobile collection of organisms preserved in alcohol; iv) flannelgraph, used for the assessment of the retention of information (metal panel simulating a river, the process of degradation, and its consequences for the aquatic community); c) gameplaying: "playing with the bioindicators of water quality", to reinforce the retention of the material presented (game in the round, where the participants represent the aquatic community and a process of degradation is simulated, resulting in consequences for the ecosystem and the benthic organisms; d) field visit to the streams, using a simplified protocol for the characterisation of ecological conditions - adapted from Callisto et al. (2002a) - during which bioindicator organisms are collected and the conservation status of the aquatic ecosystem is discussed.

\section{Results and Discussion}

\subsection{Physical and chemical features}

The riparian vegetation within the study area presented three strata - arboreal, shrub, and herbaceous - with a canopy that varies in height between 12 and $23 \mathrm{~m}$. The leaf litter was mostly homogeneous, with occasional deeper deposits. There was relatively little anthropogenic impact or erosion, although a number of exotic plant species - Bambusa vulgaris Schrad, Bambusa vulgaris vittata McClure, and Elaeis guineensis Jacq - were observed in both areas. The canopy is continuous on both stream sides, with few natural clearings.

The results of Callisto et al. (2002a) protocol applied in the studied area indicated the presence of few anthropogenic impacts, either adjacent to the streams or within the surrounding area. The aquatic ecosystems were classified by the protocol as natural, varying between 71 points for P04 and 95 points for P06. The principal factors determining the differences among sampling points were a) the presence of exotic plant species; b) instability of the margin (small areas of erosion); and c) sedimentary deposits on the bottom.

The waters were relatively acid, with $\mathrm{pH}$ values ranging from 5.01 at P01 to 6.17 at P06. The buffering capacity of the water (medium total alkalinity) was positive only at P02, P06, and P09 (9.08, 0.75, and $17.32 \mu \mathrm{Eq} / \mathrm{L}$ of $\mathrm{CO}_{2}$, respectively), which appears to emphasise the fragility of the ecosystem (sensu Callisto et al., 1998).

Total dissolved solids and turbidity were relatively low, reflecting the well-preserved condition of the ecosystems, with well-developed riparian forest and few areas of erosion. High levels of turbidity were recorded only in the Lagartixo sub-basin (P04), where there is some evidence of disturbances prior to the creation of the conservation unit, and P09 (Bica do Estreito sub-basin), where a small dam had been constructed. Low Total-P and Total-N were found in both sub-basins ( $<0.005$ and $<0.063$, respectively).

Throughout the study area, with the exception of P04, the sediment acts as a nutrient sink, indicated by the positive values of the oxi-redox potential. The negative value recorded at $\mathrm{P} 04(-266 \mathrm{mV})$ reflects the type of sediment at this point, which is made up of very fine particles (clay), which may result in anoxia at the bottom of the water column (Table 2), corroborating Coiado (2004).

\subsection{Diversity of freshwater bioindicators}

A total of 1333 organisms were collected, representing 32 families (Table 3 ). These included 28 families belonging to the class Insecta, two Crustacea, one Oligochaeta, and one Arachnida. The organic (leaf litter) substrate showed a much higher taxonomic richness (all 28 families) and abundance (1161 individuals) in comparison with the gravel substrate - 172 individuals representing 24 families.

The two substrates presented distinct taxonomic compositions, according to the NMS analysis (Figure 1). The availability of microhabitats appears to be an important factor determining of the composition of macroinvertebrate 


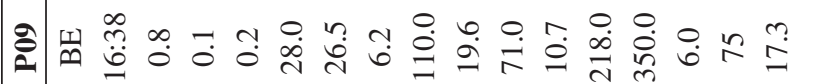

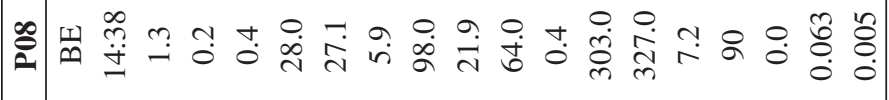

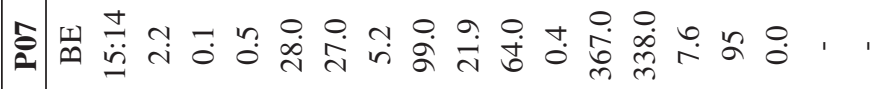

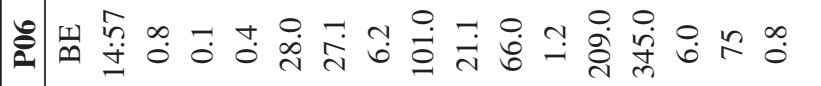

东

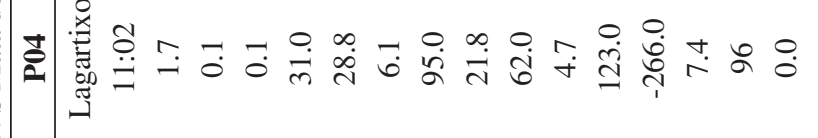

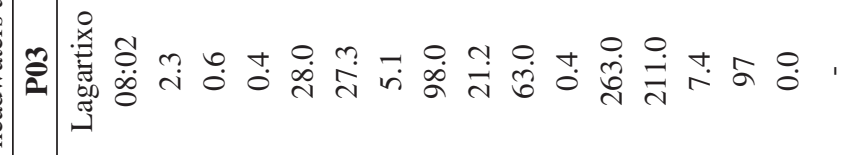

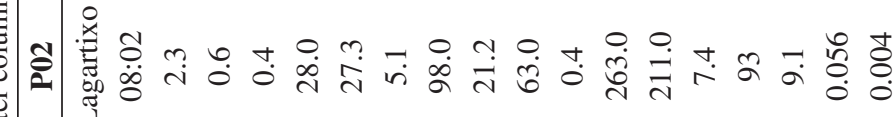

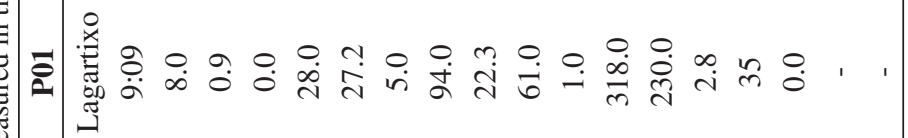




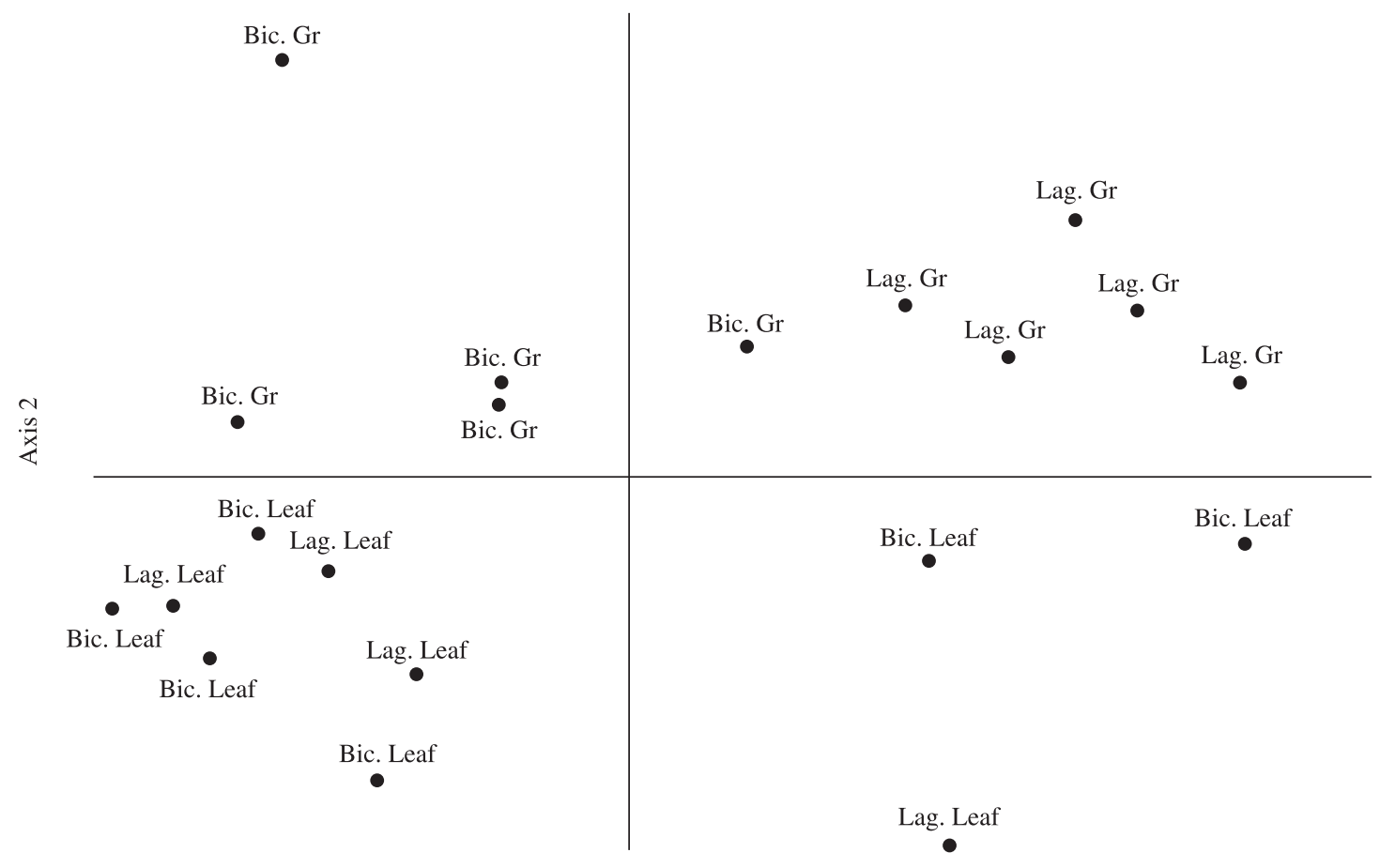

Axis 1

Figure 1. NMS analysis with samples ordination in a bi-dimensional plan (stress $=18.17)$. Bic. $=$ Bica do Estreito stream, Lag. = Lagartixo stream, $\mathrm{Gr}=$ Gravel substrate, Leaf $=$ Leaf substrate.

communities (Costa and Melo, 2008), and the difference observed between the two substrate types in the present study appear to further confirm this pattern. The partition analysis revealed a distinct distribution of diversity by substrate type (Figure 2).

Gravel showed the lowest mean richness per Surber $\left(\alpha_{1}=28 \%\right)$, which indicates that the samples were poorly representative of the region's total taxonomic richness. The $\beta_{1}$ diversity was relatively high for both substrates, however $-39 \%$ for leaves and $41 \%$ for gravel - which indicates considerable variation among points, despite their relative proximity.

The leaf litter in the Bica do Estreito is formed mainly by bamboo leaves, which fall into the stream (only 10 leaf morphotypes were found in the litter at the bottom of this stream). By contrast, the riparian vegetation of the Lagartixo sub-basin is typical of well-preserved Atlantic Forest. This determines the difference in the leaf litter found in this stream, which is characterized by a higher number of leaf morphotypes - 25 in all. However, this difference in the composition of the detritus and leaf biomass was not reflected in any major difference in the macroinvertebrate communities of the two sub-basins, as indicated by the NMS arrangement and the low diversity between streams $\left(\beta_{2}=21 \%\right.$ for the leaf substrate). In addition, neither the richness nor abundance of the leaf banks varied significantly between streams (Figure 3), which indicates that, until now, the presence of bamboo on the banks of the Bica do

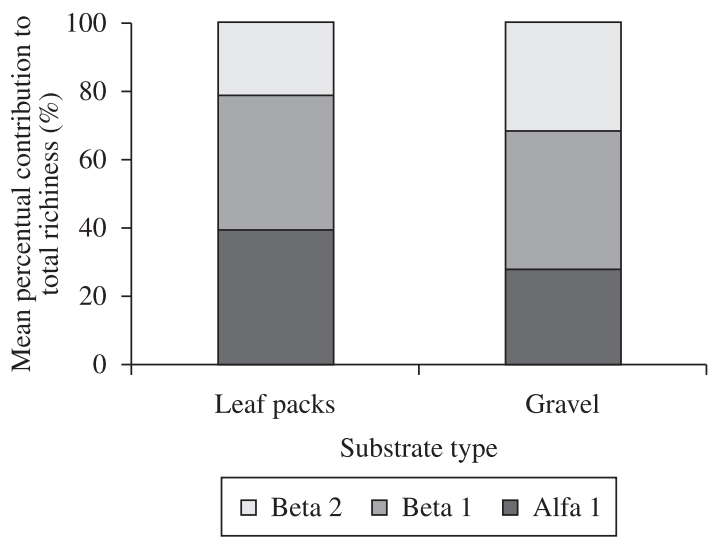

Figure 2. Additive diversity partitioning (taxonomic richness) for the two sampled substrates. $\alpha 1=$ average richness in each Surber sample, $\beta 1=$ average richness difference between Surber samples, $\beta 2=$ average richness difference between streams.

Estreito has not had a significant impact on the benthic community. The $\beta_{2}$ diversity was greater for gravel (31\%), which indicates greater heterogeneity between streams for this type of substrate.

Biotic index

The biotic benthic index applied in the present study indicated that both sub-basins had very good water 
Table 3. Taxonomic composition (ind. $/ \mathrm{m}^{2}$, average and standard deviation), total richness, total densities, evenness and Shannon Wiener diversity indexes in the Lagartixo and Bica do Estreito streams.

\begin{tabular}{|c|c|c|c|c|}
\hline \multirow{2}{*}{ Taxa } & \multicolumn{2}{|c|}{ Lagartixo } & \multicolumn{2}{|c|}{ Bica do Estreito } \\
\hline & Gravel & Leaf & Gravel & Leaf \\
\hline \multicolumn{5}{|l|}{ Annelida } \\
\hline Oligochaeta & & $11 \pm 16$ & $11 \pm 11$ & $16 \pm 29$ \\
\hline \multicolumn{5}{|l|}{ Arthropoda } \\
\hline \multicolumn{5}{|l|}{ Arachnoidea } \\
\hline Hidracarina & $2 \pm 5$ & $4 \pm 6$ & $2 \pm 5$ & $111 \pm 236$ \\
\hline \multicolumn{5}{|l|}{ Crustacea } \\
\hline \multicolumn{5}{|l|}{ Decapoda } \\
\hline \multicolumn{5}{|l|}{ Brachyura } \\
\hline Goyazana castelnaui* & & $4 \pm 6$ & & \\
\hline Ostracoda & & & & $2 \pm 5$ \\
\hline \multicolumn{5}{|l|}{ Insecta } \\
\hline \multicolumn{5}{|l|}{ Coleoptera } \\
\hline Elmidae & $5 \pm 10$ & $76 \pm 70$ & $93 \pm 71$ & $324 \pm 284$ \\
\hline Scirtidae & $2 \pm 5$ & $27 \pm 37$ & $7 \pm 10$ & $149 \pm 212$ \\
\hline Pitilodactilidae & & & $2 \pm 5$ & $9 \pm 20$ \\
\hline \multicolumn{5}{|l|}{ Diptera } \\
\hline Ceratopogonidae & $5 \pm 10$ & $2 \pm 5$ & & $2 \pm 5$ \\
\hline Chironomidae & $13 \pm 9$ & $267 \pm 317$ & $13 \pm 9$ & $84 \pm 98$ \\
\hline Empididae & & $11 \pm 14$ & $2 \pm 5$ & \\
\hline Simuliidae & $2 \pm 5$ & $309 \pm 354$ & $13 \pm 14$ & $391 \pm 428$ \\
\hline Stratiomyidae & & $2 \pm 5$ & & \\
\hline Tipulidae & $2 \pm 5$ & $7 \pm 15$ & $11 \pm 19$ & $4 \pm 6$ \\
\hline \multicolumn{5}{|l|}{ Ephemeroptera } \\
\hline Baetidae & & $7 \pm 6$ & & $22 \pm 26$ \\
\hline Leptophlebiidae & $27 \pm 26$ & $104 \pm 145$ & $9 \pm 12$ & $67 \pm 64$ \\
\hline \multicolumn{5}{|l|}{ Heteroptera } \\
\hline Guerridae & $2 \pm 5$ & & & \\
\hline Naucoridae & & & $4 \pm 6$ & $4 \pm 6$ \\
\hline Veliidae & & & & $13 \pm 30$ \\
\hline \multicolumn{5}{|l|}{ Lepidoptera } \\
\hline Pyralidae & & $2 \pm 5$ & $7 \pm 10$ & \\
\hline \multicolumn{5}{|l|}{ Megaloptera } \\
\hline Corydalidae & & & & $2 \pm 5$ \\
\hline \multicolumn{5}{|l|}{ Odonata } \\
\hline Calopterigidae & $2 \pm 5$ & $4 \pm 6$ & & $4 \pm 6$ \\
\hline Coenagrionidae & $2 \pm 5$ & $29 \pm 32$ & & $22 \pm 44$ \\
\hline Libellulidae & & $2 \pm 5$ & & $2 \pm 5$ \\
\hline Gomphidae & & & $2 \pm 5$ & \\
\hline Megapodagrionidae & & $2 \pm 5$ & & \\
\hline \multicolumn{5}{|l|}{ Plecoptera } \\
\hline Perlidae & & & $9 \pm 12$ & $49 \pm 41$ \\
\hline \multicolumn{5}{|l|}{ Trichoptera } \\
\hline Leptoceridae & $7 \pm 10$ & $200 \pm 398$ & & $2 \pm 5$ \\
\hline Helicopsychidae & $37 \pm 19$ & $2 \pm 5$ & $40 \pm 51$ & $16 \pm 22$ \\
\hline Hydropsychidae & $2 \pm 5$ & $18 \pm 23$ & $38 \pm 36$ & $78 \pm 46$ \\
\hline Hydroptilidae & & & $2 \pm 5$ & \\
\hline Odontoceridae & $2 \pm 5$ & & & \\
\hline Philopotamidae & & & $2 \pm 5$ & $113 \pm 185$ \\
\hline Richness & 15 & 21 & 18 & 23 \\
\hline Abundance & 51 & 491 & 121 & 670 \\
\hline Shannon Wiener & 2.073 & 1.975 & 2.202 & 2.266 \\
\hline Eveness & 0.7655 & 0.6486 & 0.7619 & 0.7226 \\
\hline Total density & 566.67 & 5455.56 & 1344.44 & 7444.44 \\
\hline
\end{tabular}

*H. Milne-Edwards (1853) 

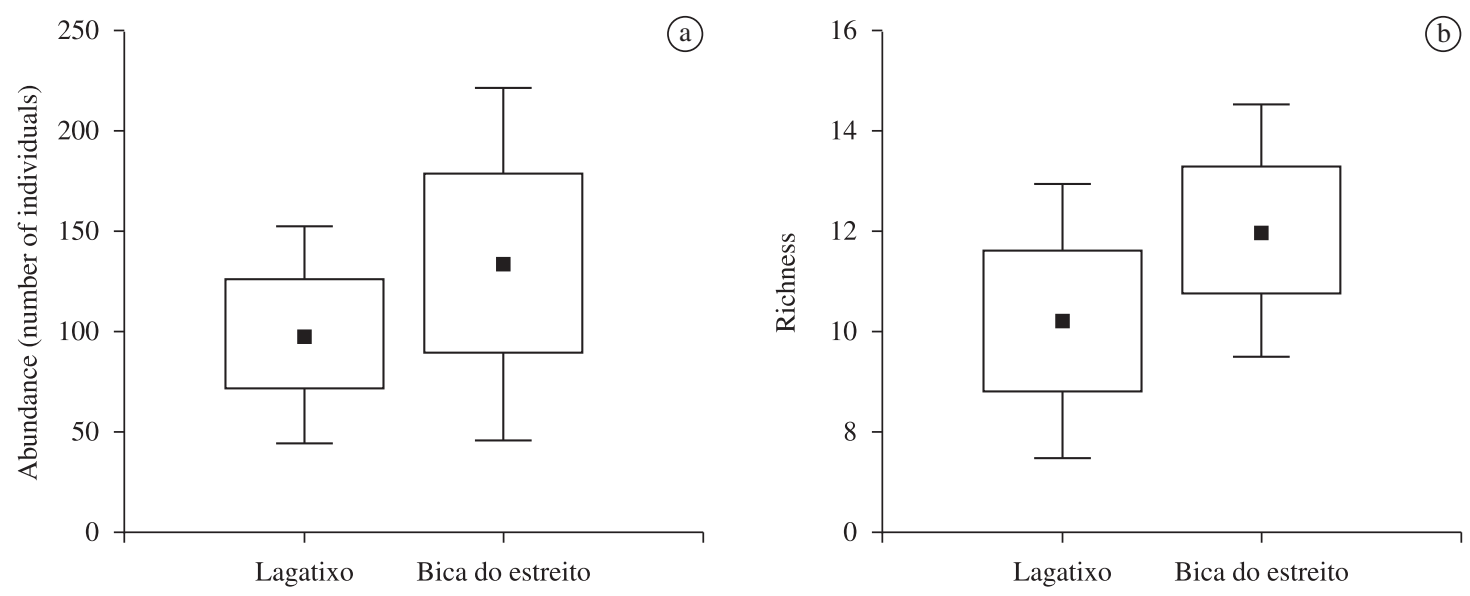

Figure 3. Average and standard deviation of abundance (a) and richness (b) in the leaf packs of the Lagartixo and Bica do Estreito streams.

quality (total score $=30$ ). This score was based on the high taxonomic richness of the area, in addition to the presence of a number of organisms that are sensitive to pollution and other anthropogenic impacts, such as larvae of the orders Plecoptera, Ephemeroptera, and Trichoptera. The importance of the taxonomic richness as a metric that reflects the diversity of benthic organisms and the health of freshwaters is well known (Ferreira et al., 2011).

Collector-gatherers and collector-filterers, which feed on fine particles of organic matter, predominated in both areas (Figure 4). The proportion of predators was slightly higher $(14 \%)$ in the Bica do Estreito in comparison with the Lagartixo (10\%), although the proportions of grazers were slightly reversed. According to Tomanova et al. (2006), the gathering-collectors are frequently the dominant trophic group in tropical streams because of the abundance of resources produced by the rapid degradation of allochthonous organic matter.

Drifting invertebrates

A total of 137 invertebrate specimens were collected in the drift nets, representing 18 taxa: Baetidae (29), Calopterygidae (2), Ceratopogonidae (4), Chironomidae (12), Coenagrionidae (1), Elmidae (6), Gerridae (4), Hidracarina (17), Hydropsychidae (1), Hydroptilidae (1), Leptoceridae (4), Leptophlebiidae (5), Philopotamidae (5), Scirtidae (14), Simuliidae (18), Stenochiromus (5), Tipulidae (1), and Veliidae (8). Once again, no significant differences were found in the composition or community structure of these organisms between the two sub-basins, although some groups were restricted to one or a few sample points. While the discharge of the Bica do Estreito was greater, density was slightly higher in the Lagartixo (Table 4).

Ichthyofauna

A total of 57 fishes were collected during the present study. These specimens represented eight different species distributed in seven genera belonging to seven different families, and five orders. Almost two-thirds (62\%) of the specimens belonged to the order Characiformes, followed by Perciformes (21\%), Synbranchiformes (11\%),

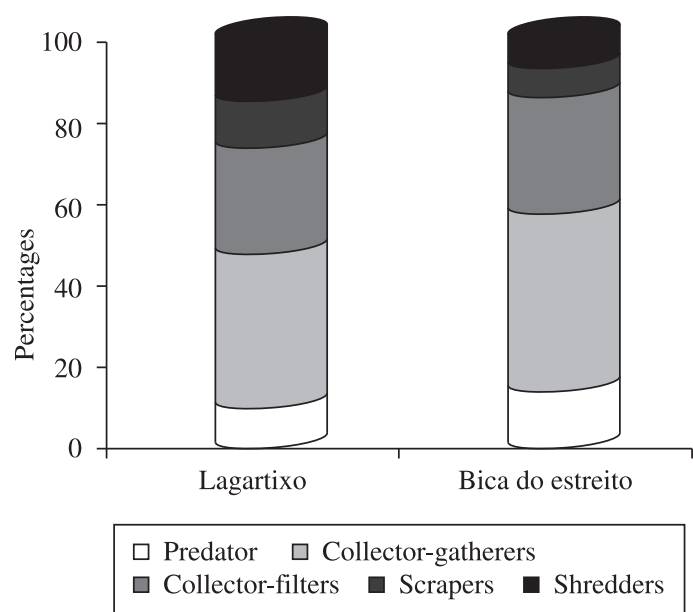

Figure 4. Functional feeding groups in Lagartixo and Bica do estreito streams at RVS Mata do Junco, Sergipe.

Siluriformes (3\%), and Gymnotiformes (3\%). While Neotropical aquatic ecosystems tend to be dominated by siluriforms and characiforms (Castro, 1999), only the latter predominated in the present study. In general, the species identified in the present study were typical of those found in other hydrographic basins, such as those of the Rio São Francisco (Alves and Pompeu, 2010) and Rio Grande (Castro et al., 2004).

The scarcity of siluriform fish may be related to the preference of these animals for specific types of habitat, where they normally seek refuge during the course of the day. In addition, fish may often be relatively rare in headwater streams, such as those studied here (Tupinambás et al., 2007). Obviously, a more comprehensive inventory of the ichthyofauna of the streams surveyed here and the rest of the Japaratuba basin would require the collection of a much more systematic sample, including a much longer period, covering seasonal variations in climate, and the 
Table 4. Biotic indices of sampled reaches in Lagartixo (L) and Bica do Estreito (B) streams, RVS Mata do Junco, Capela, SE.

\begin{tabular}{|c|c|c|c|c|c|c|}
\hline & \multicolumn{3}{|c|}{ Lagartixo } & \multicolumn{3}{|c|}{ Bica do Estreito } \\
\hline & P1 & $\mathbf{P 2}$ & P3 & P1 & $\mathbf{P 2}$ & P3 \\
\hline Richness & 13 & 5 & 5 & 5 & 10 & 7 \\
\hline $\begin{array}{l}\text { Number of individuals } \\
\text { in } 24 \text { hours of drift }\end{array}$ & 34 & 13 & 6 & 24 & 30 & 30 \\
\hline Density (Ind./m³) & 0.00911 & 0.02006 & 0.00496 & 0.03885 & 0.00356 & 0.00359 \\
\hline Shannon Wiener & 2.397 & 1.179 & 1.561 & 1.326 & 1.959 & 1.781 \\
\hline Evenness & 0.9346 & 0.7323 & 0.9697 & 0.8237 & 0.8509 & 0.9154 \\
\hline
\end{tabular}

use of additional capture techniques, such as seine nets and electric fishing (Castro et al., 2004).

For the analysis of stomach contents, the 39 specimens included 22 Astyanax gr. bimaculatus (Linnaeus, 1758) (Characidae), eight Geophagus brasilienses (Quoy \& Gaimard, 1824) (Cichlidae), four Synbranchus marmoratus Bloch, 1795 (Symbranchidae), two Gymnotus carapo Linnaeus, 1758 (Gymnotidae), and one each of the species Hoplias malabaricus (Boch, 1794) (Erythrinidae), Rhamdia quelen (Quoy \& Gaimard, 1824) (Pimelodidae), and Callichthys callichthys (Linnaeus, 1758) (Callichthyidae). Benthic macroinvertebrates were found in the stomachs of all the specimens, except that of $H$. malabaricus, which had an empty stomach.

Nine benthic invertebrate taxa were identified in the stomach contents of these specimens: Ostracoda, Hidracarina, Ceratopogonidae, Chironomidae, Simuliidae, Tipulidae, Libellulidae, Calamoceratidae, and Pyralidae. The taxonomic richness of these organisms was relatively low in comparison with the results of other studies based on a similar approach (Callisto et al., 2002b; Tupinambás et al., 2007). For more reliable and conclusive data on these parameters, a much larger sample of fish would be required, in particular of benthophagous species, which were not collected in the present study and would increase the inventory of aquatic insects (Fagundes et al., 2008).

Training in environmental education

A total of 34 pupils were involved in the three visits to the study area. These visits were based on the concept that "socialisation of successful experiences in the divulgation of scientific knowledge on water through the 'Bioindicators of Water Quality' programme, which is based on the production and distribution of informative material on methods and applications of game-playing". Given the assumption that environmental education aims primarily at the development of "citizenship", the use of a game-playing approach is especially important because it transforms information on environmental problems into a simple and attractive format, capable of increasing the efficiency of the process (Giron, 1992).

All the pupils classified the area as natural, based on scores of between 80 and 96 points. By visiting this wellpreserved spring, the pupils were able to both develop a sense of responsibility, and better understand the conditions of the watercourses of this sub-basin as a whole.
The type of activity developed during the present study, which involved lecturers and students from different institutions, environmental protection agencies, and the local community, represents an efficient strategy for the practical application of the knowledge accrued in the classroom, with major benefits for all parties involved.

Validation of multi - and interdisciplinary experiences

The activities developed during the field course by the 20 students from the two postgraduate programmes in ecology and conservation (UFMG and UFS), members of the local community, and personnel of the government environment agencies resulted in extensive interaction and the exchange of multi - and inter-disciplinary experiences. The study provided a preliminary evaluation of the environmental quality of the Mata do Junco Wildlife Refuge, applying a rapid ecological assessment approach to the investigation of two sub-basins, and their aquatic habitats. This initiative provided the first ecological parameters for the basin of the Japaratuba river, as well as contributing towards the development of local environmental education strategies. The experience was further the basis of a series of recommendations for the development of public policies in the state, involving institutions such as UFS, EMBRAPA (Federal Agricultural Research Agency) and SEMARH.

Acknowledgements - We sincerely thank the collaboration of the managers of the Protected Area Mata do Junco, technicians of the Secretaria de Meio Ambiente e Recursos Hídricos and to our local friends who kindly allowed the use of field facilities and provided extensive logistical advice and information on the study area during the Field Course in March, 2010. This research was funded by the PROCAD-NF-CAPES Programme between the Postgraduate Programmes in Ecology of UFS and UFMG, with additional support from CNPq, FAPEMIG and US Fish and Wildlife. We thank Marcelo Brito (UFS) and Carlos Bernardo Mascarenhas Alves (UFMG) for their contribution to fish species identification, Solange Nascimento for the crustacean species identification, and Stephen F. Ferrari for review and English editing. This paper was written while MC was a sabbatical visitor (CAPES fellowship n ${ }^{\circ} 4959 / 09-4$ ) at the IMAR, Universidade de Coimbra, Portugal.

\section{References}

ALVES, CBM. and POMPEU, PS., 2010 A fauna de peixes da bacia do rio das Velhas no final do século XX. In ALVES, CBM. and POMPEU, PS. (Orgs.). Peixes do rio das Velhas: passado e presente. Belo Horizonte: Argumentum. p. 167-189. cap. 3. 
ADENEY, M., CHRISTENSEN, NMJr. and PIMM, SL., 2009. Reserves protected against deforestation fires in the Amazon. Plos One, vol. 4, no. 4, p. 5014. PMid:19352423. PMCid:2660414. http://dx.doi.org/10.1371/journal.pone.0005014

BARBOSA, FAR. and CALLISTO, M., 2000. Rapid assessment of water quality and diversity of benthic macroinvertebrates in the upper and middle Paraguay River using the Aqua-Rap approach. Verhandlungen Internationale Vereinigung für Theoretische und Angewandte Limnologie, vol. 27, p. 2688-2692.

BOYERO, L., 2000. Towards a global stream ecology. Trends in Ecology and Evolution, vol. 15, p. 390-391. http://dx.doi. org/10.1016/S0169-5347(00)01957-1

BROOKS, TM., MITTERMEIER, RA., FONSECA, GAB., GERLACH, J., HOFFMANN, M., LAMOREUX, JF., MITTERMEIER, CG., PILGRIM, JD. and RODRIGUES, ASL., 2006. Global biodiversity conservation priorities. Science, vol. 313, no. 5783, p. 58-61. PMid:16825561. http://dx.doi. org/10.1126/science.1127609

BUSS, DF. and VITORINO, AS., 2010. Rapid Bioassessment Protocols using benthic macroinvertebrates in Brazil: evaluating of taxonomic sufficiency. Journal of the North American Benthological Society, vol. 29, no. 2, p. 562-571. http://dx.doi.org/10.1899/09-095.1

CALLISTO, M., ESTEVES, FA., GONÇALVES, JF. and FONSECA, JJL., 1998. Benthic macroinvertebrates as indicators of ecological fragility of small rivers ("igarapés") in a bauxite mining region of Brazilian Amazonia. Amazoniana, vol. 15, no. $1 / 2$, p. $1-9$.

CALLISTO, M., FERREIRA, W., MORENO, P., GOULART, MDC. and PETRUCIO, M., 2002a. Aplicação de um protocolo de avaliação rápida da diversidade de hábitats em atividades de ensino e pesquisa (MG-RJ). Acta Limnologica Brasiliensia, vol. 4, no. 1, p. 91-98

CALLISTO, M., VONO, V., BARBOSA, FAR. and SANTEIRO, SM., 2002b. Chironomidae as a food resource for Leporinus amblyrhynchus (Teleostei: Characiformes) and Pimelodus maculatus (Teleostei: Siluriformes) in a Brazilian reservoir. Lundiana, vol. 3, p. 67-73.

CARMOUZE, J-P., 1994. O metabolismo dos ecossitemas aquáticos: fundamentos teóricos, métodos de estudo e análises químicas. São Paulo: Ed. Edgard Blücher, FAPESP. 253 p.

CASTRO, RMC., 1999. Evolução da ictiofauna de riachos Sul-americanos: padrões gerais e possíveis processos causais. In CARAMASCHI, EP., MAZZONI, R. and PERES-NETO, PR. (Eds.). Ecologia de Peixes de Riachos. p. 139-155. Série Oecologia Brasiliensis C, vol. 6 .

CASTRO, RMC., CASATTI, L., SANTOS, HF., MELO, ALA. , MARTINS, LSF. , FERREIRA, KM. ,GIBRAN, FZ. , BENINE, RC. , CARVALHO, M. , RIBEIRO, AC., 2004. Estrutura e composição da ictiofauna de riachos da bacia do Rio Grande no Estado de São Paulo, Sudeste do Brasil. Biota Neotropica, Campinas, v. 4, no. 1, p. 1-34.

CHAGAS, RRD., 2009. Levantamento das populações de Callicebus coimbrai Kobayashi and Languth, 1999 em fragmentos da Mata Atlântica no Sul do Estado de Sergipe, Brasil. Aracaju, Sergipe, Aracajú: Universidade Federal de Sergipe. 61 p. Dissertação de Mestrado em Desenvolvimento e Meio ambiente.

CHERNOFF, B., BARRIGA, R., FORSYTH, A., FOSTER, R., LEON, B., MACHADO-ALLISON, A., MAGALHÃES, C., MENEZES, N., MOSKOVITS, D., HORTEGA, H. and
SARMIENTO, J., 1996. Aqua-RAP. Rapid Assessment Program for the conservation of aquatic ecosystems in Latin America. Mimeo. 8 p. Annex.

COIADO, EM., 2004. Suspended sediment load with zero velocity point corrected. Water Engineering Research, vol. 2, p. 112-127.

COSTA, SS. and MELO, AS., 2008. Beta diversity in stream macroinvertebrate assemblages: among-site and among-microhabitat components. Hydrobiology, no. 598, p. 131-138.

CUNHA, RGL., 2001. Estudo de disponibilidade na unidade de balanço da bacia hidrográfica do rio Japaratuba. SEPLANTEC/ SRH. 30 p.

FAGUNDES, CK., BEHR, ER. and KOTZIAN, CB., 2008. Diet of Iheringichthys labrosus (Siluriformes, Pimelodidae) in the Ibicuí river, southern Brazil. Iheringia Série Zoologia, vol. 98, p. 60-65.

FERREIRA, RAF., ROCHA, JCS., NETO, EMS., SANTOS, PL. and ABREU, LD. 2007. Diagnóstico de Nascentes. Relatório Técnico RVS Mata do Junco. 120 p.

FERREIRA, WR., PAIVA, LT. and CALLISTO, M., 2011. Development of a benthic multimetric index for biomonitoring of a Neotropical watershed. Brazilian Journal of Biology, vol. 71, no. 2, in press. PMid:17696645. PMCid:1945070.

FONSECA, GAB., RODRIGUES, CM., MIDGLEY, G., BUSCH, J., HANNAH, L. and MITTERMEIER, RA., 2007. No forest left behind. PLoS Biology, vol. 5, no. 8, p. 216. http://dx.doi. org/ 10.1371/journal.pbio.0050216

GIRON, D., 1992. Classificação e análise de materiais lúdicos - o sistema ESAR. O direito de brincar (a Brinquedoteca). Ed.Scritta. p. 171-181. PMid:19236450

GOLTERMAN, HL., CLYMO, RS. and OHMSTAD, MAM., 1978. Methods for physical and chemical analysis of freshwaters. London: IBP Handbook Blackwell. 156 p. no. 8

HANSON, T., BROOKS, TM., FONSECA, GAB., HOFFMANN, M., LAMOREUX, JF., MACHLIS, G., MITTERMEIER, CG., MITTERMEIER, RA. and PILGRIM, JD., 2009. Warfare in biodiversity hotspots. Conservation Biology, vol. 23, no. 3, p. 578-587. http://dx.doi.org/10.1111/j.1523-1739.2009.01166.x

JOPPA, LN., LOARIE, SR. and PIMM, SL., 2008. On the protection of "protected areas". Proceedings of the National Academy of Sciences of the United States of America, vol. 105, no. 18 , p. 6673-6678.

MACKERETH, FJH., HERON, J. and TALLING, JF., 1978. Water analysis: some revised methods for limnologists. Cumbria: Freshwater Biological Association. 120 p. no. 36.

MALTICHIK, L. and CALLISTO, M., 2004. The use of rapid assessment approach to discuss ecological theories in wetland systems, Southern Brazil. Interciência, vol. 29, p. 219-223.

MYERS, N., MITTERMEIER, RA., MITTERMEIER, CG., FONSECA, GAB. and KENT, J., 2000. Biodiversity hotspots for conservation priorities. Nature, vol. 403, p. 853-858. http:// dx.doi.org/10.1038/35002501

MITTERMEIR, RA., FONSECA, GAB., RYLANDS, AB. and BRANDON, K., 2005. A brief history of biodiversity conservation in Brazil. Conservation Biology, vol. 19, no. 3, p. 601-607. http:// dx.doi.org/10.1111/j.1523-1739.2005.00709.x

MITTERMEIER, RA. and FORSYTH, A., 1992. Conservation Priorities: the role of Rap. In PARKER, TA. and CARR, JL. (Eds). Rapid Assessment Program: status of forest remnants in 
the Cordillera de la Costa and Adjacent Areas of South-western Ecuador. Conservation International. p. 172.

MORENO, P. and CALLISTO, M., 2006. Benthic macroinvertebrates in the watershed of an urban reservoir in the south-eastern Brazil. Hydrobiologia, vol. 560, p. 311-321. http://dx.doi.org/10.1007/ s10750-005-0869-y

MOULTON, TP. and WANTZEN, KM., 2006. Conservation of tropical streams - special questions or conventional paradigms? Aquatic Conservation: Marine and Freshwater Ecosystems, vol. 16, p. 659-663. http://dx.doi.org/10.1002/AQC.814

POMPEU, PS., CALLISTO, M. and ALVES, CBM., 2005. The effects of urbanization on biodiversity and water quality in the rio das Velhas basin, Brazil. American Fisheries Society Symposium, vol. 47, p. 11-22.

SCARANO, FR., 2007. Global and local conservation priorities. Science, vol. 318, p. 1377-1378. PMid:20378803. http://dx.doi. org/10.1126/science.318.5855.1377b
STUART, SN., WILSON, EO., MCNEELY, JA., MITTERMEIER, RA. and RODRIGUES, JP., 2010. The barometer of life. Science, vol. 328, no. 5975, p. 177. http://dx.doi.org/10.1126/science.1188606

TOMANOVA, S., GOITIA, E. and HELESIC, J., 2006. Trophic levels and functional feeding groups of macroinvertebrates in Neotropical streams. Hydrobiologia, vol. 556, p. 251-264. http:// dx.doi.org/10.1007/s10750-005-1255-5

TUPINAMBÁS, TH., CALLISTO, M. and SANTOS, GB., 2007. Benthic macroinvertebrate assemblages structure in two headwater streams, south-eastern Brasil. Revista Brasileira de Zoologia, vol. 24 , no. 4, p. 887-897.

VEECH, JA., SUMMERVILLE, KS., CRIST, TO. and GERING, JC., 2002. The additive partitioning of species diversity: recent revival of an old idea. Oikos, vol. 99, p. 3-9.

YULE, CM., BOYERO, L. and MARCHANT, R., 2010. Effects of sediment pollution on food webs in a tropical river (Borneo, Indonesia). Marine and Freshwater Research, vol. 61, p. 204-213. http://dx.doi.org/10.1071/MF09065 
